\title{
Pious and Impious Christian Rulers According to Egyptian Historiography and Hagiography: A First Survey of the Evidence
}

An effective way to study the evolving attitude of the Alexandrian patriarchate towards the political power is to trace the image of the good Christian emperor in the multiplicity of its historical representations. In this regard, wide-ranging research is needed on how the see of Alexandria presents itself on the religious and political level over the centuries in the histories and the hagiographical texts produced within the bishopric or in the circles close to it, deeply connected to the institutional and collective dimension of the church. ${ }^{1}$ In this context the process should be highlighted that leads from the archival activity of the patriarchate to the production of tales, traditions, stories, which are based on the documentation preserved in the archives, ${ }^{2}$ but are also provided with their own life, their own images, their own grammar. The patriarchate produced historiographical works conceived of as a sequence of documents and polemical narratives, here and there provided with short anecdotes. It also created histories of martyrs and saints, normally connected to this same documentation, but marked by a more pronounced tendency to relate episodes or to express a historical assessment through images and symbols. The permanence and the reworking of the same motifs and images through the ages served the function of emphasizing the sense of continuity and eternal orthodoxy of Alexandria. ${ }^{3}$

The texts selected in the present contribution are the expression not simply of an individual author, but rather of a network of church relations, in which multiple voices try to emerge - the voices of different groups defending their interests, their traditions, and their contribution to the life of the Egyptian church, such as the clergy, the monks, and engaged laity. I recently investigated ${ }^{4}$ the changing role of historical

\footnotetext{
1 For a presentation of the historiography of the episcopate of Alexandria see A. Camplani, "The religious identity of Alexandria in some ecclesiastical histories of Late Antique Egypt", in L'historiographie tardo-antique et la transmission des savoirs, ed. Ph. Blaudeau, P. van Nuffelen (MillenniumStudien zu Kultur und Geschichte des ersten Jahrtausends n.Chr. 55), Berlin - Munich - Boston 2015, 85-119.

2 On the archives of the bishopric of Alexandria see A. Camplani, "Setting a Bishopric / Arranging an Archive: Traces of Archival Activity in the Bishopric of Alexandria and Antioch”, in Manuscripts and Archives. Comparative Views on Record-Keeping, ed. A. Bausi, C. Brockmann, M. Friedrich, S. Kienitz (Studies in Manuscript Cultures 11), Berlin 2018, 231-272.

3 I have studied the figures and symbols of church and political power in the hagiographical production tied to the bishopric in A. Camplani, "La percezione della crisi religiosa calcedonese in alcuni testi storici e agiografici prodotti negli ambienti dell'episcopato di Alessandria", Adamantius 19 (2013) 240-255.
}

4 Camplani (cf. fn. 1) 86-89.

2 OpenAccess. (C) 2021 Alberto Camplani, published by De Gruyter. (cc) BY-NC-ND This work is licensed under the Creative Commons Attribution-NonCommercial-NoDerivatives 4.0 International License. 
documentation in fourth-to-seventh-century histories. In it, I described the progressive loss of references to real documents, the growth of pious narratives concerning clerics, monks, members of the élite, and the emperor himself, and a growing emphasis on the cultic buildings, financed by the engaged believers, and their impact on the urban visibility of Christianity. ${ }^{5}$

These writings reveal not only the patriarchal see's perception of its own evolution, ${ }^{6}$ but also its changing evaluation of both its political and religious relationships with the emperor and remaining patriarchates of the Mediterranean world, i.e., Constantinople, Antioch, Jerusalem, and Rome, thus presenting the outline of the culture and the ecclesiological orientation of a church milieu. For that reason, we will pay the greatest attention to the notion of geo-ecclesiology as proposed by Philippe Blaudeau, which is a particular reworking of some conceptual tools belonging to "geopolitics" applied specifically to that network of congregations which constituted the Christian world of the fourth-sixth centuries. Geo-ecclesiology, in other terms, is the historical approach which considers the patriarchates in their reciprocal relationship, as well as in their connection to the political power, with particular attention paid to issues such as territorial jurisdiction, areas of influence and resistance, self-representation, and propaganda. ${ }^{7} \mathrm{~A}$ few examples of the series of questions which geo-ecclesiology is intended to answer could be the following: Which criteria determined the religious and political importance of a patriarchal see such as Alexandria to be the religious representative of the Empire? Were they apostolicity, martyrdom, orthodoxy, or a privileged connection to the political power? Which tools promoted a Christian metropolis in the context of the Empire: the writing of political and ecclesiological pamphlets? The circulation of dossiers of documents and canonical legislation? The organisation of spectacular manifestations? At the same time, after considering some similarities, Blaudeau warns against believing that there is no difference between geo-ecclesiology and geo-politics: for instance, in the former, the breaking of communion and the use of violence are, at least in theory, not con-

5 On the role of the philoponoi and the rich Christian élite of Alexandria see A. Camplani, "The Transmission of Early Christian Memories in Late Antiquity: On the editorial activity of laymen and philoponoi" in Between Personal and Institutional Religion. Self, Doctrine, and Practice in Late Antique Eastern Christianity, ed. B. Bitton-Ashkelony, L. Perrone (Cultural Encounters in Late Antiquity and the Middle Ages 15), Turnhout 2013, 129-153.

6 See A. Camplani, “Tempo delle origini e tempo della storia nella percezione dell'episcopato di Alessandria durante la tarda antichità", in Tempo e storia in Africa / Time and History in Africa, ed. A. Bausi, A. Camplani, S. Emmel (Africana Ambrosiana 4), Milano 2019, 3-32.

7 On the notion of geo-ecclesiology, see Ph. Blaudeau, Alexandrie et Constantinople (451-491): de l'histoire à la géo-ecclésiologie (Bibliothèque des écoles françaises d'Athènes et de Rome 327), Rome 2006, 6-8 and chapter 3; see also A. Martin, "Introduction", in Histoire "acéphale" et index syriaque des lettres festales d'Athanase d'Alexandrie. Introduction, texte critique, traduction et notes par A. Martin avec la collaboration pour l'édition et la traduction du texte syriaque de M. Albert (SC 317), Paris 1985, 34-67. 
sidered as normal conflict resolution tools as in the latter. ${ }^{8}$ From the point of view of the intellectual antecedents of the geo-ecclesiological perspective, it should be asked whether, just as geopolitics refers to Thucydides, geo-ecclesiology could take its inspiration from the complex historical perspective offered by Eusebius in his historical writings. ${ }^{9}$

This paper explores the representation of the good Christian emperor in two sections. The first section discusses the representation of the emperor from Athanasius to Timothy Aelurus: the Christian emperor is outlined in the historical accounts as a person who exercises power in the service of the society and the church. This prerogative can be put at work either in a good and intelligent way or in a bad one, depending on the emperor's religious choices, which in turn are due to his capacity to manage the pressures coming from both his entourage (wife, other members of the family, religious party, group of bishops) and his personality (self-control, emotions, anger).

In the second section, we will trace a re-reading of the fourth- and fifth-century imperial history in post-Chalcedonian sources in order to promote a new model of leadership. Figures like Constantine, Jovian, but also the two Theodosii, and others are subject to revision, which leads to the creation of stories in which a new image of the good Christian emperor emerges: he must support not only orthodoxy, but also the fight against the remnants of paganism, and above all give financial contribution to the cultic buildings in order to promote the urban visibility of Christianity.

\footnotetext{
8 See also Ph. Blaudeau, "What is Geo-Ecclesiology: Defining Elements Applied to Late Antiquity (Fourth-Sixth Centuries)", in Late Antiquity in Contemporary Debate, ed. R. Lizzi Testa, Newcastle (UK), 156-173, at 156-157.

9 See Ph. Blaudeau (cf. fn. 8): "If geo-ecclesiology is an intimate part of the discipline of history, it is in some ways conditioned by its intellectual parentage. Just as the specialist in International Relations engages in long, fruitful discussion with Thucydides, because he was the first and he proposed major generalizations about power and imperialism that could lead to a theoretical approach in this regard, so the geo-ecclesiologist is in constant dialogue with the authors of ecclesiastical history, and with Eusebius of Caesarea in particular. Based on extensive original documentation, this remarkable output is indeed a discourse on the Church itself, that is to say, etymologically an ecclesiology with a strong awareness of time (...). So, to him, the true Church is historically guaranteed by the ethics of its members, and by their commitment to their faith to the point of martyrdom. It is still manifested demonstratively and effectively by the communion of the four sees distinguished by apostolic tradition (Rome, Alexandria, Antioch and Jerusalem), which is also, incidentally, in fundamental agreement with canons 6 and 7 of Nicaea."
} 


\section{Athanasius' Influence on the Historiography of the Patriarchate until Timothy Aelurus: Constantine, Constantius, and Jovian}

An extraordinarily important event in the fourth century was destined to be influential on the reciprocal representations of the Egyptian church and the empire: On November 7th, 335 Athanasius was exiled to Trier by Constantine - universally considered as the first Christian emperor - because of the condemnation by the bishops convened in the council of Tyre in the summer of 335 and other questions affecting the public order of the empire. After Constantine's death on 22 May 337, Athanasius was immediately recalled to his unoccupied see by Constantine II, one of the emperor's sons and successors (June 337). ${ }^{10}$

From that moment on, one of the main activities of Athanasius, which left deep traces in his writings and in the subsequent historiography, was to elaborate an apologetic version of facts about Constantine. In this version, the emperor - in a momentary break in anger against him when in Constantinople (7 November 335) - exiled Athanasius to save him from persecution by his Arian enemies. This account is questionable from the point of view of historical plausibility, ${ }^{11}$ but was influential to the point of affecting the behaviour of Constantine II, as we will see later. After Constantine's death in 337, and in particular in the 350s, Athanasius began to emphasize the difference between him and his son Constantius (who in the meantime had remained the sole emperor). One the one hand, he attributed Constantine's uncertainties concerning Arius not to the weakness of his Christian faith but to the pressures of his ecclesiastical advisors (in particular Eusebius of Nicomedia) and his definitive anti-Arian choice (on whose sincerity and firmness Athanasius hoped to convince his readers) to his wisdom as the legitimate leader of the Christian Empire. On the other hand, he portrayed Constantius as a hidden supporter of Arianism, and accused him of being unable to govern the Empire and contradictory even in his attitude towards Athanasius. A new question was born: that of the orthodoxy of the Christian emperor.

10 T.D. Barnes, Athanasius and Constantius. Theology and Politics in the Constantinian Empire, Cambridge (Ma.) - London 1993, 20 -33; A. Martin, Athanase d'Alexandrie et l'Église d'Égypte au IVe siècle (328-373) (Cahiers des Écoles françaises d'Athènes et de Rome 216), Rome 1996, 357-387.

11 Martin (cf. fn. 10) 393-394, on the basis of Constantine II's letter preserved in Ath., apol. sec. 87.4. 


\subsection{Athanasius}

Therefore, a brief consideration of Athanasius' works is unavoidable while exploring the historiography of the Alexandrian episcopate. ${ }^{12}$ Four writings in particular are relevant to our argument, since they discuss Constantine's and Constantius' role in ecclesiastical affairs: ${ }^{13}$ the Epistula ad Serapionem de morte Arii, ${ }^{14}$ Epistula ad episcopos Aegypti et Libyae, ${ }^{15}$ Apologia secunda contra Arianos, ${ }^{16}$ and Historia Arianorum. ${ }^{17}$

The Epistula ad Serapionem de morte Arii (De morte Arii) has been dated to different periods of Athanasius' career, from 340 to 358. I am in favour of a later dating (around 357/8), ${ }^{18}$ a period in which the other works of the group were being composed or reworked. The dating of this work, however, does not change the core of my argument. The Athanasian account appears very simple on first reading: ${ }^{19}$ in the period after the Council of Nicaea, Arius was invited by his supporters to declare his faith in front of Constantine. According to Athanasius, the main points of Arius's heretical discourse were missing from his pronouncement. Constantine was inclined to accept his declaration, but the bishop of Constantinople strongly opposed Arius' entry into the church. When Arius, following his sponsors, tried to enter the church, a sudden gastro-intestinal attack provoked his death, depriving him of communion with the Catholic Church. The passage concerning Constantine deserves to be quoted $(2.1-3):^{20}$

12 The standard reference book on Athanasius is now Athanasius Handbuch, ed. P. Gemeinhardt, Tübingen 2011.

13 L.W. Barnard, "Athanasius and the Roman State”, Latomus 36 (1977) 422-437, reprinted in his Studies in Church History and Patristics (ANA $\Lambda$ EKTA B $\Lambda$ ATA $\triangle \Omega N$ 28), P. C. Christou, Thessoloniki 1978, 312-328; see now K. Piepenbrink, “Athanasius und die Kaiser”, in Gemeinhardt (cf. fn. 12) $134-139$.

14 Athanasius Werke. Zweiter Band. Erster Teil. Die Apologien, ed. H.G. Opitz, Berlin 1934, 178-180. 15 Athanasius Werke. Erster Band. Erster Teil. Die Dogmatischen Schriften, 1. Lieferung, ed. K. Metzler, Berlin - New York 1996.

16 Opitz (cf. fn. 14) 87-168.

17 Opitz (cf. fn. 14) 181-230.

18 See also H. Muehlberger, “The Legend of Arius's Death: Imagination, Space, and Filth in Late Ancient Historiography”, Past \& Present: A Journal of Historical Studies 277 (2015) 3-29 (esp. 6-7), an article where the Greek and Latin historiography about Arius' death is studied and put into perspective; see also B. Stefaniw, "Epistula ad Serapionem de morte Arii”, in Gemeinhardt (cf. fn. 12) 208210, and, for a different dating, D.M. Gwynn, Athanasius of Alexandria: Bishop, Theologian, Ascetic, Father, Oxford 2012, 9.

19 Gwynn (cf. fn. 18) 10: "his vision of Arius dying on a Constantinopolitan latrine is one of the most famous images in Christian heresiology."

20 Ed. Opitz (cf. fn. 14) 178-179, English translation by A. Robertson, Select Writings and Letters of Athanasius, Bishop of Alexandria (A Select Library of Nicene and Post-Nicene Fathers of the Christian Church, Second Series, 4), Grand Rapids/MI 1891, 565a. 


\begin{abstract}
Arius had been invited by the Emperor Constantine, through the interest of Eusebius and his fellows; and when he entered the presence, the Emperor enquired of him, whether he held the Faith of the Catholic Church? And he declared upon oath that he held the right Faith, and gave in an account of his Faith in writing, suppressing the points for which he had been cast out of the Church by the Bishop Alexander, and speciously alleging expressions out of the Scriptures. When therefore he swore that he did not profess the opinions for which Alexander had excommunicated him, [the Emperor] dismissed him, saying, 'If thy Faith be right, thou hast done well to swear; but if thy Faith be impious, and thou hast sworn, God judge of thee according to thy oath.' When he thus came forth from the presence of the Emperor, Eusebius and his fellows, with their accustomed violence, desired to bring him into the Church. But Alexander, the Bishop of Constantinople of blessed memory, resisted them, saying that the inventor of the heresy ought not to be admitted to communion.
\end{abstract}

In the Epistula ad episcopos Aegypti 19.4 we find another version of the episode: here there is only one note about the emperor, that is, his reaction to the extraordinary manner of Arius' death. "The blessed Constantine hearing of this at once, was struck with wonder to find him thus convicted of perjury."21 In contrast, Constantine's presence in De morte Arii is reported at the beginning of this affair. Athanasius suggests that the emperor could have been inclined to accept Arius' profession of faith, but at the same time a doubt arose in him about the heretic's sincerity which made him pronounce a threat about the judgment that God would have against him in case of perjury. The threat immediately became reality, establishing a strict connection between the emperor and Arius' destiny.

The other two works provide richer evidence about Athanasius' ideal of good (or bad) Christian emperors. The Apologia secunda contra Arianos (Apologia) is a personal defense by Athanasius against charges laid against him by his ecclesiastical opponents, built on rich civil and clerical documentary sources probably preserved in Alexandria's large archives. In one passage, after having reported the origins of the Melitian schism and the birth of Arianism, Athanasius deals with the Arian pressure on Constantine $(59.4-5):^{22}$

\begin{abstract}
At first (Eusebius of Nicomedia) sent to me, urging me to admit Arius and his fellows to communion, and threatened me in his verbal communications, while in his letters he [merely] made a request. And when I refused, declaring that it was not right that those who had invented heresy contrary to the truth, and had been anathematized by the Ecumenical Council, should be admitted to communion, he caused the Emperor also, Constantine, of blessed memory, to write to me, threatening me, in case I should not receive Arius and his fellows, with those afflictions, which I have before undergone, and which I am still suffering.
\end{abstract}

In this passage, in which quite a long period of ecclesiastical history is summarised, Constantine appears as someone who made his decision after having listened to his ecclesiastical advisors. Later, these same advisors, when they told the emperor that

21 Robertson (cf. fn. 20) 233a; ed. Metzler (cf. fn. 15) 60.

22 Translation in Robertson (cf. fn. 20) 131b-132a; ed. Opitz (cf. fn. 14) 139-140. 
Athanasius, according to some witnesses, had said in another circumstance that he was able to block the corn which was usually sent from Alexandria to Constantinople, provoked in Constantine that "anger" which an emperor should always keep under control (Ath., apol. sec. 87.2): ${ }^{23}$

It was proved also by the anger of the Emperor ( $\theta$ upó $)$; for although he had written the preceding letter, and had condemned their injustice, as soon as he heard such a charge as this, he was

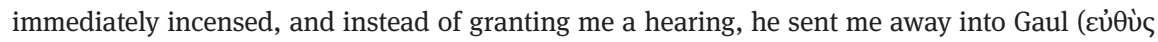

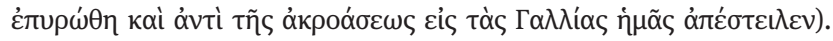

But a little later we learn that, according to Athanasius, this temporary yielding to anger was superseded by more forward-looking decisions, inherited and actualised by his son Constantine II. Athanasius quotes a letter by him addressed to the church of Alexandria, dated 17 June 337, that reveals what his father's real intentions were $(87.4-7):^{24}$

I suppose that it has not escaped the knowledge of your pious minds, that Athanasius, the interpreter of the adorable Law, was sent away into Gaul for a time, with the intent that, as the savageness of his bloodthirsty and inveterate enemies persecuted him to the hazard of his sacred life, he might thus escape suffering some irremediable calamity, through the perverse dealing of

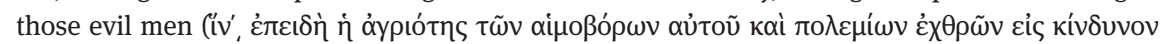

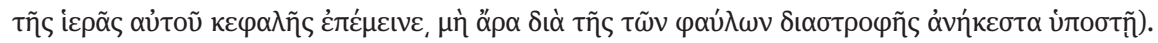
In order therefore to escape this, he was snatched out of the jaws of his assailants, and was ordered to pass some time under my government, and so was supplied abundantly with all necessaries in this city, where he lived, although indeed his celebrated virtue, relying entirely on divine assistance, sets at nought the sufferings of adverse fortune. Now seeing that, it was the fixed intention of our master Constantine Augustus, my Father, to restore the said Bishop to his own place, and to your most beloved piety, but he was taken away by that fate which is common to all men, and went to his rest before he could accomplish his wish.

It is really impressive to see how much Athanasius' propaganda has influenced the young emperor. When looking at the general plan of the Apologia, the imperial materials which are used in Athanasius' defense should not escape the attention of the reader. In the first section, devoted to the Council of Serdica, there emerge letters written by Constantius to Athanasius before and after Gregory's death (51.6.7.8: invitation to the court), and those notifying Athanasius' restoration to his see in Alexandria (54-56). The quotation of these letters serve the function of showing Constantius' contradictory attitude, who receives Athanasius, but at the same time is ready to arrest him. In the second part, the focus is on Constantine as an author of letters: while urging Athanasius to admit Arius, he is also ready to condemn the bishop's enemies $(59,61,68,70)$. His changing attitude is due not so much to the weakness of his personality, like in Constantius' case, but to the pressures he receives from

23 Translation in Robertson (cf. fn. 20) 146a; ed. Opitz (cf. fn. 14) 166.

24 Translation in Robertson (cf. fn. 20) 146a; ed. Opitz (cf. fn. 14) 166. 
the diverse religious groups active around him, whose perspectives he has to consider before choosing a course of action. ${ }^{25}$ It is only after the council of Tyre that, according to Athanasius, Constantine begins to suspect that Athanasius may have been the object of unjust treatment on the part of his ecclesiastical colleagues (86). His decision to restore him as bishop of Alexandria is thus inherited by Constantine II.

The Historia Arianorum is characterised by a more violent tone and can be classified as opposition literature, political satire, engaged historiography, and a real manifesto against Constantius. ${ }^{26}$ But it is here that broader considerations emerge about the relationship between state and church. The quoted documents are few and coincide with those reported in the Apologia, while other documents and events lacking in the Apologia are simply alluded to, such as the famous decree by Constantine in which the Arians are compared to the disciples of Porphyry (Ath., hist. Ar. 51.1: “Porphyrians"), or the story of Arius' death (ibid.). On the other hand, the Historia Arianorum contains long pieces of polemics, in which Constantius is denounced as the Antichrist $(74,77)$ and is compared to such Biblical figures as Saul, Ahab, and Pontius Pilate $(68-69)$. He is also represented as cruel against his relatives (69) and incapable of resisting the pressures of his advisors, lacking one of the prerogatives of a good emperor, the capacity of making an independent decision (69.2): ${ }^{27}$

But when I compare his letters, I find that he does not possess common understanding, but that his mind is solely regulated by the suggestions of others and that he has no mind of his own at

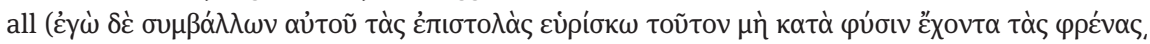

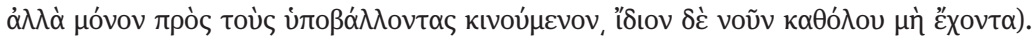

Thus, the good relationship and reciprocal independence between the church and the empire is compromised (52.3): ${ }^{28}$

For if a judgment had been passed by Bishops, what concern had the Emperor with it? (દi yò $\rho$

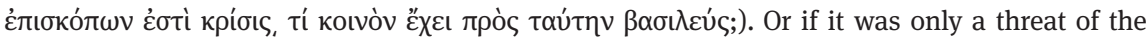
Emperor, what need in that case was there of the so-named Bishops?

25 Barnard (cf. fn. 13) 319: "He was concerned that Christianity should be the religion of the Empire - but what kind of Christianity was not his main concern as long as unity and peace (concordia) were preserved.”

26 Barnes (cf. fn. 10) 126: "The underlying assumption of the HA is that Athanasius is a victim of a systematic policy of persecution mounted by the Arians against Christ and his true believers ever since the days of Constantine, and that this policy has been rendered possible only by secular support. (...) But it is Constantius above all who has fostered the persecution of orthodoxy and interfered improperly in the affairs of the Christian church. (...). His constant complaint that the emperor interferes in the affairs of the church is not in fact directed against interference as such, but against imperial actions of which he disapproves (...) Athanasius implicitly asserts that emperors have a right to overrule church councils - provided that they do so in the interest of orthodoxy rather than heresy." 27 Translation in Robertson (cf. fn. 20) 296a; ed. Opitz (cf. fn. 14) 221.

28 Translation in Robertson (cf. fn. 20) 289a; ed. Opitz (cf. fn. 14) 213. 
Athanasius ascribes to Ossius of Cordova a famous discourse in which Matthew 22:21 is used to proclaim the right of the independence of the church from the state $(44.6-8):^{29}$

God has given you kingship, but has entrusted us with what belongs to the church. Just as the man who tries to steal your position as emperor contradicts God who has placed you there, so too you should be afraid of becoming guilty of a great offense by putting the affairs of the church under your control. It is written, "Render unto Caesar the things that are Caesar's and unto God the things that are God's" (Mt 22:21). Hence neither do we (bishops) have the right to rule over the world nor do you, emperor, have the right to officiate in church.

Barnard states that "Athanasius claimed the right of the Church to manage its own affairs without imperial interference - indeed the sum total of his charges against Constantius derive from the one premise that the Emperor had infringed ecclesiastical order and mingled Roman sovereignty and the constitution of the Church." ${ }^{30} \mathrm{He}$ adds that it is "unlikely that Athanasius' goal was a complete dualistic severance of Church and State. Indeed when it suited him he had no qualms in appealing to the imperial court. His ideal was probably cooperation between Church and State with the bishops having freedom to decide Church matters in their own gatherings and the Emperor having the right to maintain the peace of the Church and to defend its faith." 31

\subsection{From the Historia Episcopatus Alexandriae to Timothy Aelurus}

It is clear that the question of the orthodoxy of the emperor becomes more and more important over time, particularly during the Theodosian age. Barnes' conclusions can only be shared: "By the end of the fourth century Christian orthodoxy had been added to the traditional list of virtues required in a legitimate emperor." ${ }^{32}$ The process appears to have been gradual.

The official history of the Alexandrian episcopate $(H E p A)^{33}$ deserves a brief analysis from this point of view. Here the Athanasian influence is clear, in the sense that

29 Barnes' translation (cf. fn. 10) 175; ed. Opitz (cf. fn. 14) 208.

30 Barnard (cf. fn. 13) 325.

31 Barnard (cf. fn. 13) 328.

32 Barnes (cf. fn. 10) 174.

33 For an edition of the new Gə'əz version and Latin parallels, see A. Bausi, A. Camplani, "The History of the Episcopate of Alexandria (HEpA): Editio minor of the fragments preserved in the Aksumite Collection and in the Codex Veronensis LX (58)", Adamantius 22 (2016) 249-302, where a bibliography is offered of the editions of the single pieces composing the $H E p A$; for the section of the HEpA concerning Nicaea and Athanasius (Historia Athanasii or Historia acephala), see A. Martin, M. Albert (cf. fn. 7). 
Constantine and Constantius are presented, by way of documents, as the two contrasting incarnations of the Christian emperor, the orthodox and the heretical. This contrast is inserted in a kind of history with canonical interests which promotes the rights and the jurisdiction, as well as the geo-ecclesiological position, of the great episcopal see.

$H E p A$ was composed gradually between the end of the fourth and the beginning of the fifth century, with possible later editions based on third- and fourth-century documents. This work, which was originally written in Greek, is preserved in two distinct languages, Latin and Gə‘əz, while minor fragments and quotations survive in Greek and Syriac. The Ethiopic version, identified by Alessandro Bausi, is preserved within a codex $(\operatorname{siglum} \Sigma)$, dating from the thirteenth century at the latest: it contains a canonical-liturgical collection composed of translations from the Greek which appear to belong to the Aksumite period (fourth to seventh centuries $\mathrm{CE}$ ). The Latin version has been known since Scipione Maffei (1738) thanks to an old Latin uncial codex of the Biblioteca Capitolare in Verona (seventh-eighth century, Codex Veronensis LX [58], siglum $V$ ), the two tomes of which contain documents concerning the church of Africa and a rich and varied canonical and synodical collection. Some items of the two collections, which coincide in more than one case, have been proven to belong to a lost Greek History of the Episcopate of Alexandria, to be distinguished from both the later Coptic History of the Church and Copto-Arabic History of the Patriarchs of Alexandria, to which we will come back later. In regard specifically to the HEpA, it should be remarked that the two canonical collections contain both shared and unique materials. $V$ and $\Sigma$ have in common the epistle by four martyr-bishops to the schismatic Melitius of Lycopolis to dissuade him from proceeding to illegitimate ordinations, the epistle by Peter of Alexandria to his church through which Melitius is excommunicated (CPG 1641), and a short historical narrative interposed between the two (CPG 1668). The parallels between $V$ and $\Sigma$ include other documents as well, such as a letter by Constantine on the council of Nicaea (CPG 8517) and his letter against Arius (CPG $2041=8519)$. Each version also has its own material: the narrative on the early history of the Patriarchate of Alexandria, enriched by three lists of the Egyptian bishops appointed by them, and the account of some episodes of the Melitian schism are preserved only by $\Sigma$, while the life of Athanasius (the so-called Historia acephala or Historia Athanasii), as well as the letters sent by him from the Council of Serdica (CPG 2111, 2112), ${ }^{34}$ are preserved only by $V$.

Through the documents it quotes, a portrayal emerges of the good / bad Christian emperor. Constantine is credited with the convocation of the Council of Nicaea, the foundation of every future form of orthodoxy: $:^{35}$

34 Athanasius Werke. Dritter Band. Erster Teil: Dokumente zur Geschichte des arianischen Streites, ed. H.C. Brennecke, U. Heil, A. von Stockhausen, A. Wintjes, Berlin - New York 2007, 186-250.

35 C.H. Turner. Ecclesiae Occidentalis Monumenta Iuris Antiquissima. Canonum et conciliorum graecorum interpretationes latinae... opus postumum, Oxford 1939, I 104. 


\begin{abstract}
Synodus Nicena sub Alexandro episcopo Alexandrie imperatore Constantino. Multa igitur seditione facta beato Alexandro cum suis de mala mente Arrii, uictoriosissimus imperator Constatinus scripsit illi et omnibus episcopis occurrere, colligens concilium omnium episcoporum in Nicena ciuitate, et conuenerunt uniuersi statuto die.

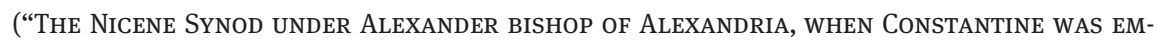
PEROR. Therefore, since great was the discord occurred to the blessed Alexander with his (supporters) regarding Arius' evil opinion, the emperor Constantine victoriosissimus wrote to him and all the bishops to come, convening a council of all the bishops in the city of Nicaea, and they all gathered on a fixed date").
\end{abstract}

There are two protagonists in this short passage: the bishop of Alexandria, persecuted by the heretics, and Constantine, who, in order to defend the Alexandrian orthodoxy, summons all the bishops to a council. This sentence highlights a privileged relationship between Constantine and Alexander that never in fact existed. Constantine, in the face of the religious disorder, acts as a good emperor should act: he does not make a decision on his own, does not impose a choice, but invites all bishops (uniuersi) to decide. Only in this way does the relationship between church and state find its balance, because the state does not intervene on its own but gives the church the means to give an effective outcome to her decisions.

Two letters by the same Constantine are quoted in the HEpA that support the Alexandrian cause: one is addressed to the Alexandrians on the occasion of the Council of Nicaea, and the other is a famous "decree" in which Arius is attacked and condemned as a "Porphyrian," also alluded to in Historia Arianorum 51. Thus, Constantine is presented as an anti-Arian and anti-heretical emperor. ${ }^{36}$

The situation is different under Constantius, whose letters that recalled Athanasius from the second exile are mentioned with the clear intention of showing his contradictory attitude against the hero of the HEpA. The emperor is responsible, with his brother Constans, for the convocation of the Council of Serdica (343), ${ }^{37}$ which, as the $H E p A$ portrays it, could have been a good event if the Arian heresy, supported by Constantius, had not caused it to fail.

Equally interesting is HEpA's treatment of Jovian, the "Christian" emperor (Historia acephala $4.3-4.7):^{38}$

36 Turner (cf. fn. 35) 631-633; A. Bausi, “The accidents of transmission: On a surprising multilingual manuscript leaf", Adamantius 22 (2016) 310-317.

37 Turner (cf. fn. 35) 637: Tunc \{t\}temporis ingerebantur molestiae imperatoribus synodum conuocare, ut insidiarentur Paulo episcopo Constantinupolitano per sugestionem Eusebii Acacii Theodori Valentis Stephani et sociorum ipsorum, et congregata est synodus consolat. Constantii III et Constantis II aput Sardicam ("At that time annoyances were brought to the emperors to convene a synod, in order to undermine Paul bishop of Constantinople, on the advice of Eusebius, Acacius, Theodore, Valens, Stephen and their colleagues, and a synod was convened in Serdica under the third consulate of Constantius and the second of Constans").

38 A. Martin, M. Albert (cf. fn. 7) 152, 158; Robertson (cf. fn. 20) 498a, b. 
Quo in his locis degente, cognitum est Iulianum imperatorem mortuum et Iouianum christianum imperatorem. Ingressus igitur Alexandriam latenter episcopus, aduentu eius non pluribus cognito, occurrit nauigio ad imperatorem Iouianum. Et post, ecclesiasticis rebus conpositis, accipiens litteras, uenit Alexandriam et intrauit in ecclesiam methir XIX die, consolatu Iouiani et Varroniani, ex quo exiit Alexandria secundum preceptum Iuliani usquedum aduenit predicto die methir XIX post annum unum et menses III et dies XXII. (...). Cum autem episcopus Athanasius ueniret de Antiochia Alexandriam, consilium fecerunt Arriani Eudoxius, Theodorus, Sophronius, Euzoius et Ilarius [pertinentem] et constituerunt Lucium, presbyterum Georgii, interpelare imperatorem Iouianum in palatio et dicere quae in exemplaribus abentur. Hic autem minus necessaria intermissimus.

("And while he was staying in these places, it was learned that the Emperor Julian was dead, and that Jovian a Christian was Emperor. So the Bishop entered Alexandria secretly, his arrival not being known to many, and went by sea to meet the Emperor Jovian, and afterwards, Church affairs being settled, received a letter, and came to Alexandria and entered into the Church on the xix day of Athyr Coss. Jovianus and Varronianus. From his leaving Alexandria according to the order of Julian until he arrived on the aforesaid xix day of Athyr after one year and iii months, and xxii days. (...) Now when the Bishop Athanasius was coming from Antioch to Alexandria, the Arians Eudoxius, Theodore, Sophronius, Euzoius and Hilary took counsel and appointed Lucius, a presbyter of George, to seek audience of the Emperor Jovian at the Palace, and to say what is contained in the copies. Now here we have omitted some less necessary matter").

We learn from both this passage and a letter by Athanasius preserved in Coptic ${ }^{39}$ that complaints were presented by members of the anti-Athanasian clergy to the emperor on October 30th, 363 at Antioch against his reinstallation as bishop of Alexandria. A very interesting account of this episode, with the transcriptions of the dialogue exchanges, is preserved in one of the Athanasian collections ( $\alpha$-Sammlung) titled Petitiones arianorum. Here it is said that the Arians (Lucius was among them) reached the emperor while he was leaving the city on horseback, but that he refused to listen to them and went out. A second attempt was later made, however the accusations against Athanasius did not convince Jovian. A third attempt, with more detailed charges, was equally unsuccessful, as Jovian declared that he believed in the total orthodoxy of Athanasius. The fourth attempt, led by Lucius alone as Jovian was coming back to the city, was rejected too..$^{40}$ In the original form of the $H E p A$, this episode was quoted in its integrity (it has been summarised in Sozom. hist. eccl. 5.2-4), and the text probably knew a certain amount of circulation, given its capacity to meet the popular taste.

39 Ed. A. Camplani, "Atanasio e Eusebio tra Alessandria e Antiochia (362-363): Osservazioni sul Tomus ad Antiochenos, l'Epistula catholica e due fogli copti (edizione di Pap. Berol. 11948)", in Eusebio di Vercelli e il suo tempo, ed. E. Dal Covolo, R. Uglione, G.M. Vian (Biblioteca di Scienze Religiose, 133), Rome 1997, 191-246. See also Athanasius Werke. Dritter Band, Erster Teil. Dokumente zur Geschichte des arianischen Streites, 5. Lieferung, ed. H.Ch. Brennecke, U. Heil, A. von Stockhausen, Berlin - New York 2020, 668-669.

40 Ed. Athanasius Werke. Zweiter Band. Die “Apologien”, 8. Lieferung, ed. H.Ch. Brennecke, U. Heil, A. von Stockhausen, Berlin - New York 2006, 358-361. 
At the same time, the passage mentions a letter sent by Jovian to Athanasius. In this letter, preserved in the $\alpha$-Sammlung, Athanasius is recognised officially as the legitimate bishop of Alexandria and restored to his see. In the Athanasian collections, this letter, together with a letter sent by the same Athanasius to Jovian (containing the Nicene symbol), demonstrates the new alliance between the religious power and the political power, once the latter is represented by an orthodox emperor. $^{41}$

The attitude of the HEpA is similar to Theodoret of Cyrrhus's historical work. In Historia ecclesiastica 4.2-3 it is precisely the description of Athanasius' relationship with Jovian, corroborated by the long quotation of a letter of the former to the latter, which has the function of giving the reader the image of the good ruler; that is, one who appears as a strict Nicene, friend of the "orthodox" bishops, and ready to sustain economically the life of the clergy. ${ }^{42}$ Here Theodoret draws his materials from the Eustathian section of the Antiochene archives, where documents in favour of Athanasius were preserved. ${ }^{43}$

Finally, it should be remarked that Jovian's period follows the one in which both Constantinople and Antioch are preyed upon by divisions and heretics: the HEPA devotes a dramatic paragraph to each of them, which implicitly shows by way of contrast the excellence of Alexandria. Simply stated, according to the HEpA the Alexandrian bishops (Peter, Athanasius, and, before them, Mark the evangelist) are united by their personal martyrdom, ecclesiastical rigour, the defence of canonical rules, and the orthodox faith. These virtues are fundamental to the ideology of the Alexandrian episcopate because they distinguish Alexandria from the other eastern métropoleis, especially Constantinople (which moreover lacks an apostolic foundation), thereby making Alexandria the candidate most suited to provide religious leadership for the eastern Roman Empire. This identification occurred during the episcopate of Theophilus (385-412), when the ideological elements, subsequently deployed by Cyril, Dioscorus, Timothy Aelurus, and Peter Mongos, came into existence. ${ }^{44}$ These ideological elements included the view to propose Alexandria as the religious leader in the East, a close relationship with the imperial power, the emphasis placed upon the Council of Nicaea, and a complex conception of the history of the Alexandrian episcopate. ${ }^{45}$

41 Ed. in Brennecke, Heil, von Stockhausen (cf. fn. 40) 357.

42 Ed. Théodoret de Cyr., Histoire ecclésiastique. Livres III-V, texte grec de L. Parmentier et G.C. Hansen, annotation par J. Bouffartigue, Introduction par A. Martin, traduction par P. Canivet (Sources chrétiennes 530), Paris 2009, 185-197.

43 See A. Camplani (cf. fn. 2) 250-252, 259-262.

$44 \mathrm{Ph}$. Blaudeau, "Pierre et Marc. Remarques sur la revendication d'une relation fondatrice entre sièges romain et alexandrin dans la seconde moitié du $\mathrm{V}^{\mathrm{e}}$ siècle”, in Pietro e Paolo. Il loro rapporto con Roma nelle testimonianze antiche. XXIX incontro di studiosi dell'antichità cristiana, Roma 4-6 maggio 2000 (Studia Ephemeridis Augustinianum 74; Rome: Istituto Patristico Augustinianum, 2001), 577-591.

45 Blaudeau (cf. fn. 7). 
Timothy Aelurus' historiographical activity draws the most important features of its style from Athanasius and the HEpA, as well as from their ideology. While a reader could argue that the anti-Chalcedonian bishop was concerned above all with contemporary history based on most of the short fragments of his works, there are rare passages in which we perceive that the events were contextualised in a longer period of time, the fourth century. ${ }^{46}$

However, we are here interested more in the conceptions of power, empire, and emperor that emerge from Timothy's writings. A series of fragments published by Nau recalls the major events of the period from the first to the second Council of Ephesus (431-449) and then recounts those following the accession of Marcian to the throne, which led to the catastrophe of the Council of Chalcedon (451), when bishop Dioscorus was condemned and sent into exile. ${ }^{47}$ Some of the fragments try to establish a connection between the Council of Chalcedon and the contemporary events taking place in Rome. ${ }^{48}$ The writer wants his readers to believe that the impiety of the council had both caused the Vandal invasion of 455 and announced the coming of the Antichrist and the end of times, motifs found also in Athanasius's Historia Arianorum. In the Plerophories of John Rufus ${ }^{49}$ we find the same catastrophic tones and an explicit connection between pope Leo's Tome and the Vandal invasion of the city of Rome, the city in which the Tome was written. Here again the Council of Chalcedon is interpreted by Timothy as the sign of the coming of the Antichrist, while his church is portrayed as the orthodox minority, persecuted by a political power that has succumbed to a heresy. To the true believers of the persecuted church, Timothy, bishop and historian, offers a theological interpretation of ongoing and recent developments. ${ }^{50}$ The events of the Council of Chalcedon have destroyed the balance of powers that was typical of the previous age, when Cyril and Dioscorus were patriarchs in Alexandria and the empire was ruled by Theodosius the Younger (Plerophoriae 36): ${ }^{51}$

46 A. Camplani, "A Syriac fragment from the Liber historiarum by Timothy Aelurus (CPG 5486), the Coptic Church History, and the archives of the bishopric of Alexandria," in Christianity in Egypt: literary production and intellectual trends in late antiquity, ed. P. Buzi, A. Camplani (Studia Ephemeridis Augustinianum 125), Rome 2011, 205-226.

47 F. Nau, Documents pour servir à l'histoire de l'église nestorienne (PO 13), Paris 1919, 202-217. $48 \mathrm{Nau}$ (cf. fn. 47) 215-216.

49 Plerophories 89, ed. F. Nau, Jean Rufus, évêque de Maïouma. Plérophories (PO 8), Paris 1912, $152-$ 154.

50 For a presentation of Timothy's historiography and his considerations about the situation of Christianity after the council of Chalcedon, see E.J. Watts, "Interpreting Catastrophe: Disasters in the Works of Pseudo-Joshua the Stylite, Socrates Scholasticus, Philostorgius, and Timothy Aelurus," Journal of Late Antiquity 2 (2009) 79-98 (esp. 92-96); Id., "John Rufus, Timothy Aelurus and the Fall of the Western Roman Empire", in Romans, Barbarians, and the Transformation of the Roman World. Cultural Interaction and the Creation of Identity in Late Antiquity, ed. R. Mathisen, D. Shanzer, Farnham/UK - Burlington/VT 2011, 97-106 (in particular 134-135).

$51 \mathrm{Nau}$ (cf. fn. 49) 83. 


\begin{abstract}
At this time, with the permission and the will of God, it happened that, because of our many sins, our venerable Emperor Theodosius died, a year after the Second Council of Ephesus. His successor did not follow his burning zeal for the faith. Therefore, all the affairs of the church were troubled and their outcome was contrary to the law which had been made by the Venerable Theodosius, worthy of remembrance, against the heretics, from then until now. The god-fearing are persecuted and in fact every blasphemous and rebellious tongue can speak against Christ with freedom of speech.
\end{abstract}

Timothy shows how controversial the evaluation of Marcian's reign and religious policy was: ${ }^{52}$

(the Chalcedonians) proclaim him (Marcian) a believer and God-fearing, as one equipped with the zeal of piety, he that only at the end (of his life) and with difficulty was made worthy of the empire by God. (They say) that he possessed the zeal of piety, meaning obliquely that the blessed Theodosius did not think in an orthodox manner, he and those before him who were orthodox emperors, up to the time when Marcian took the kingdom, at the end (of his life) and with difficulty.

The age of the two Theodosii (I and II), to which the patriarchs Theophilus, Cyril, and Dioscorus belonged, is considered a golden age in which relations between church and state were fruitful, as both parties, according to their different competences, supported the true faith. It is in this context that heresy could be targeted and heretics exiled: the civil and ecclesiastical punishment of Nestorius was approved by God, who inflicted on him a terrible and exemplary death. Timothy draws on the narrative style of Athanasius; his image of Nestorius' tongue rotten and reduced to pieces ${ }^{53}$ is mirrored in the guts of Arius scattered on the ground as described by Athanasius. On the other hand, the judgment on Marcian's reign shows an awareness of those traditions concerning Marcian's late accession to the power and his particular relationship with Pulcheria, Theodosius II's sister, that will be developed by hagiographical texts such as the Life of Dioscorus and the Encomium of Macarius of Tkow.

\title{
2 The Later Historiographical and Hagiographical Production (Sixth to Ninth Centuries)
}

In order to study the image of the emperor over time, we will take in consideration two late histories, which draw on older sources; the Church History $(\mathrm{CHC})$ produced in the sixth century and preserved in Coptic, and the History of Patriarchs (HP), produced in the eleventh century. Some late Coptic texts will be used to help interpret the two works.

$52 \mathrm{Nau}$ (cf. fn. 47) 216.

$53 \mathrm{Nau}$ (cf. fn. 49) 84-85. 
$\mathrm{CHC}^{54}$ has been recovered gradually ${ }^{55}$ from fragmentary Coptic manuscripts and from other witnesses, in particular the parallel passages of the HP. The career of Timothy Aelurus (d. 477) is described in the last part of the $\mathrm{CHC}$, making his episcopate the accepted terminus post quem for the composition of the work. From the fragments of two Coptic manuscripts we can deduce that this work was divided into two parts: a first part, poorly preserved, containing a translation of (at least) some sections of Eusebius' History of the Church, and concerning the period until the Diocletianic persecution; a second part, completely original, narrating the events from Peter I to Timothy Aelurus. From both an index to a section of the text and a colophon we learn that the work was further divided into twelve books, each called "his-

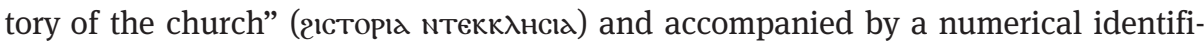
cation. $^{56}$

In comparison with the $H E p A$, the scope of the $\mathrm{CHC}$ is broader, as its focus extends to the whole eastern Mediterranean, even if the starting point is always Alexandria. This is proven both by the use of Eusebius in the first part for periods and events in which Alexandria has no role to play, in addition to the attention paid to the situation of the church in the whole East in its second half.

The $\mathrm{CHC}$ is one of the sources used by Mawhūb b. Mansūr b. Mufarriğ in the eleventh century to compose the second work to be studied here, the HP. This long work, which heavily depends on previous historical writings, is structured as a sequence of lives of patriarchs, as indicated by its Arabic title: Siyar al-Bi'ah al-Muqaddasah ("biographies of the Holy Church"). Alongside the biography of each patriarch, various political, social, and ethnic events are recorded in a format that varies according to the tastes of the original authors from whom the final editor draws his materials. ${ }^{57}$

54 An edition of the first and second part of the Coptic history is published on the web site of the Corpus dei manoscritti copti letterari: http://www.cmcl.it. See the text in Storia della Chiesa di Alessandria, ed. T. Orlandi, 2 vol. (Testi e Documenti per lo Studio dell'Antichità 17; 31), Milano - Varese $1968-1970$.

55 For additional fragments, see D.W. Johnson, "Further Fragments of a Coptic History of the Church. Cambridge Or.1699R”, Enchoria 6 (1976) 7-18; T. Orlandi, “Nuovi frammenti della Historia Ecclesiastica copta, in Studi in onore di Edda Bresciani, ed. S.F. Bondí, Pisa 1985, 363-384.

56 On the sources, cf. T. Orlandi, Studi Copti. 1. Un encomio di Marco Evangelista, 2. Le fonti copte della Storia dei Patriarchi di Alessandria, 3. La leggenda di S. Mercurio (Testi e Documenti per lo Studio dell'Antichità 22), Milano 1968; T. Orlandi, “The Coptic Ecclesiastical History: A Survey, in The World of Early Egyptian Christianity. Language, Literature, and Social Context. Essays in Honor of David W. Johnson", ed. J.E. Goehring, J.A. Timbie, Washington, D.C. 2007, 3-24; A. Boud'hors, S. Morlet. "La version copte de l'Histoire ecclésiastique” in Eusèbe de Césarée. Histoire ecclésiastique. Commentaire. Tome I. Études d'introduction, ed. S. Morlet, L. Perrone, Paris 2012, 267-270. On the contents, see http://www.cmcl.it, which offers the critical edition: the work is classified as Clavis Coptic 0200; on the manuscript tradition, see https://atlas.paths-erc.eu/works/200.

57 Still fundamental is the volume by J. den Heijer, Mawhūb ibn Manșūr ibn Mufarriğ et l'historiographie copto-arabe. Étude sur la composition de l'Histoire des Patriarches d'Alexandrie (CSCO 513, Subsidia 53), Leuven 1989. More recent information is found in the following publications: P. Pilette "La recension primitive du texte arabe de l'Histoire des Patriarches d'Alexandrie: problématique et per- 
The HP has two recensions; the first one is called "vulgate" and has been edited twice and translated to English by Evetts, and the second one is more archaic, partially edited, but has not been translated..$^{58}$ Characterised by a variety of layers of composition, it has undergone a number of editorial additions over time. The early historians wrote in Coptic, while their successors in the eleventh century wrote in Arabic. The list of the preserved and lost sources is as follows:

1. the $\mathrm{CHC}$

2. a Coptic history about the period $412-700$ attributed to the archdeacon George, collaborator of patriarchs John III (677-686), Simon I (689-701), and Cosmas (730-731)

3. a text written by a monk named John (middle of the eighth century)

4. a history composed by another John $(865-866)$

5. a text by Michael, bishop of Tinnis (1051 or 1058)

To this Coptic material translated into Arabic, the last compiler added the biographies of Christodulos (1047-1077) and Cyril III (1078-1092), composed directly in Arabic. This composite text in turn underwent minor additions and alterations in the course of time, which have led to the vulgate form of the HP.

The HP has the same ideology of the Patriarchate, since the authors of its Coptic sources were part of circles close to the Coptic institutional church. However, when we read the work, we have to take into account a plurality of ideologies, which are interwoven but not always blended together: the ideology of the $\mathrm{CHC}$, the perspectives of the other later sources, and the opinions of the final compiler, Mawhūb. The possibility that the last compiler used the method of combining the sources is well demonstrated in some situations. For example, when one reads the "Life of Demetrius," 59 it becomes clear that a later editor compiled the story by inserting a homiletic text into the CHC's version of the story, which is in turn, translated from Eusebius' History. Similarly, Orlandi has proposed that the "Lives of Alexander and Athanasius" is the combination of two sources, one of which is the $\mathrm{CHC}$ while the other is uncertain. ${ }^{60}$

spectives", Acta Orientalia Belgica 23 (2010), 141-155; ead., "L'Histoire des Patriarches d'Alexandrie: une nouvelle évaluation de la configuration du texte en recensions.", Mus 126 (2013) 419-450; ead., L'Histoire des Patriarches d'Alexandrie: une tradition textuelle ouverte. Essai méthodologique, édition critique et traduction des Vies 17 à 26, PhD Dissertation, Université Catholique de Louvain, August 2014.

58 Editions of the version qualified as "vulgata": History of the Patriarchs of the Coptic Church of Alexandria, ed. B.T.A. Evetts, Paris 1904-1915: PO 1,2: 99-214; 1,4: 381-619; 5,1: 1-215; 10,5: 357-551. The ms. of Hamburg, which testifies to a more archaic state of the text, is edited in Severus ibn al-Muqaffa'. Alexandrinische Patriarchatgeschichte von S. Marcus bis Michael (61-767), nach der ältesten 1266 geschriebenen Hamburger Handschrift im arabischen Urtext heraugegeben, ed. C.H. Seybold, L. Gräfe, Hamburg 2012.

59 Evetts (cf. fn. 58) 154-162.

60 Orlandi, Studi copti (cf. fn. 56) 63-74. 


\title{
2.1 Revisiting Fourth Century Church History: Constantine, Constantius, Jovian
}

While the manuscripts of the $\mathrm{CHC}$ lack the account of the Council of Nicaea, a very strange story is found in the HP. We do not know if it is dependent on the lost text of the $\mathrm{CHC}$ or an addition of its compiler:

\begin{abstract}
The four sees were assembled on his account at Nicaea: Eusebius for Rome, Alexander for Alexandria, Ephesus and Antioch. Constantine, the believing prince, sat with them. So when they settled the orthodox faith, and the time of the fast and the Easter, the prince said to them: "I pray you to make the city of Constantinople a patriarchal see, because it is the seat of the prince, and likewise Jerusalem, because it is the city of the Saviour, the heavenly prince." So when they saw his humility, they did this as he prayed them. Then they cut off Arius, by the command of the prince, and Constantine wrote the excommunication of Arius by his own hand. ${ }^{61}$
\end{abstract}

Despite some inconsistencies, especially the anachronism concerning a not-yet-existing Constantinople and the reference to Ephesus as one of the patriarchates (an innovation fitting polemical purposes against the Council of Chalcedon), the text foreshadows the ideal of pentarchy and advocates the subordination of the political power to the council. This text could have been written only after Alexandria had accepted the patriarchal status of the see of Constantinople - an acceptance that can be dated to the epoch of Acacius, bishop of Constantinople (472-489), linked with the patriarch Peter Mongus in Coptic memory (480-488).

In the $\mathrm{CHC}$ the story of the relationship between Constantine and Arius is broken into two parts, so as to attribute the excommunication of the heretic to Constantine, and his readmission and unexpected immediate death to his son Constantius, against everything we learn from historical sources. ${ }^{62}$ The $\mathrm{CHC}$ introduces a speech by Bishop Alexander, addressed not to Constantine as the chronology would require, but to Constantius:

\footnotetext{
For, the emperor your father signed his (Arius') excommunication and subjected it to the prefect, and, if you investigate, you will find the document (hypomnèma). As for me, it would be not a little danger to cancel a decree which was established by the emperor, especially because your own father attended to his (Arius') excommunication at the Council which gathered us at Nicaea. ${ }^{63}$
}

61 I prefer Reda Hammad's translation of the Hamburg recension found in his 2014 dissertation: Un contributo alla nuova edizione critica della Storia dei Patriarchi di Alessandria: Vitae XXVII-XXXVII. Trascrizione, traduzione, collazione, note e commento storico, PhD Dissertation, Rome 2014. The text corresponds to Evetts (cf. fn. 58) 406-407.

62 Ed. Orlandi (cf. fn. 54) I, 22 (text), 58 (translation). The reference to the documentation is noteworthy, but the author's real knowledge of all the Nicaean documentation appears questionable, just like his supposed familiarity with the bureaucratic background of the Council.

63 Ed. Orlandi (cf. fn. 54) I, 22 (text), 58 (translation). 
This split, probably favoured by the homonymy of Constantine and Constantine II, his son, served the double function of defending Constantine from the accusation of having supported Arianism and blaming Constantius for his compromise with this heresy. ${ }^{64}$ We have seen that this tendency, already at play in Athanasius, was further developed in the HEpA through the selection of documents that bolstered the author's view, and was destined to grow during the following centuries. In the $\mathrm{CHC}$, as well as in later homiletic production, it resulted into the dissolution of the correct chronology of the fourth century and the splitting of the figure of Constantine.

In Coptic hagiography, specifically hagiographical materials organised in "cycles" according to Orlandi's suggestion, ${ }^{65}$ the Roman emperors of the fourth century are deeply transformed from their most ancient representation into symbols of the different ways of managing the political power in religious matters. As Paola Buzi has put it, Constantine "often appears completely devoid of his historic traits and reduced to an abstract 'hero' character, which has been elaborated to represent the ideal model of a sovereign rather than to reconstruct the historical facts faithfully." Buzi's analysis shows that Coptic hagiography characterises Constantine in four ways: as responsible for the release of Christians from the imperial prisons, as an advocate of orthodoxy, as an evangelizer of pagan lands, and as a builder of holy places. ${ }^{67}$ The same themes recur until medieval times, as demonstrated by the Synaxarial texts studied by $\mathrm{Ph}$. Luisier. ${ }^{68}$

64 Thus, Arius' vicissitudes and death are placed under Constantius, obviously using the account written by Athanasius in his De morte Arii. It is not clear if the author had access directly to this letter, or to the traditions to which it gave birth. See Gwynn (cf. fn. 18) 189: "by placing the recall of Arius in the reign of Constantius, the History of the Patriarchs protected the reputation of Constantine, who is praised repeatedly as the defender of Nicaea but who was in fact responsible for Arius' return from banishment after 325", and Id., "Athanasius of Alexandria in Greek and Coptic Historical Tradition" Journal of Coptic Studies 15 (2013) 43-54.

65 See for example T. Orlandi, "Hagiography" in Coptic Encyclopedia, ed. A.S. Atiya, Macmillan, New York 1991, 1191a-1197b; see also "Literature”, ibid., 1450b-1460a.

66 P. Buzi, "Re-interpreting History: Constantine and the Constantinian Age according to Coptic Hagiography", in Coptic Society, Literature and Religion, from Late Antiquity to Modern Times. Proceedings of the Tenth International Congress of Coptic Studies, Rome, September 17-22, 2012, and Plenary Reports of the Ninth International Congress of Coptic Studies, Cairo, September 15-19, 2008, ed. P. Buzi, A. Camplani, F. Contardi (Orientalia Lovaniensia Analecta 247), Leuven 2016, 1117-1128, esp. 1119. Some of the texts with which I will deal here are translated and introduced by T. Orlandi, Omelie copte, SEI, Torino 1981.

67 See In Mariam Virginem by Cyril of Jerusalem dedicated to the dormition: E.A.W. Budge, Miscellaneous Coptic Texts in the Dialect of Upper Egypt, London 1915, 49-73, A. Campagnano, Ps. Cirillo di Gerusalemme. Omelie copte sulla Passione, sulla Croce e sulla Vergine (Studi e testi per lo studio dell'antichità 65), Milano - Varese 1977, 152-195 and other texts quoted by Buzi.

$68 \mathrm{Ph}$. Luisier, "Elena e Costantino nella tradizione copta," in Costantino e l'Oriente. L'impero, i suoi confini e le sue estensioni. Atti del convegno di studi promosso dal PIO in occasione della ricorrenza costantiniana (313-2013), Roma 18 aprile 2013, a cura di M. Pampaloni e B. Ebeid (OCA 300), Rome 2016, 247-265. 
The Encomium on Athanasius is an interesting Coptic text attributed to Cyril of Alexandria that narrates several episodes of the life of Athanasius, from the time of his nomination as the secretary of Bishop Alexander to the election of Jovian and the letter with which this emperor reinstated him on the Alexandrian see. ${ }^{69}$ As in the Historia Arianorum, Constantius ${ }^{70}$ also appears in this text incapable of exercising his power with authority. He is "naï" (оүафє was easily influenced by the Arians, sent Athanasius into exile, and put George on the episcopal throne. It is striking that Isauria and Seleucia are completely missing from the list of Athanasius' places of exile. A possible explanation of this oddity has been recently offered by Victor Ghica, according to whom this toponym should be interpreted as an allusion to the council of "imperial" bishops close to Constantius II which took place on 27 September 359 in Seleucia of Isauria. The council's deci-

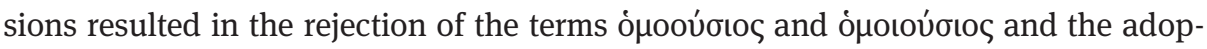

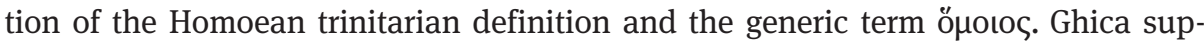
poses rightly that in the narrative describing the very beginning of Athanasius' mission at Seleucia the expression "the heritage (orciid) of his Lord (was) growing," used in reference to the flock gathered around the new preacher in exile, is a word play inserted in the text in order to support the trinitarian and orthodox use of oúrí $\alpha$ against its abolition by a council considered Arian by the bishop. ${ }^{72}$ The picture of the bad Christian emperor is completed by the characterisation of Constantius as fearful of his brother Constans. In his fear, he ceases his persecution of Athanasius at least for a period, ${ }^{73}$ a motif found in the $\mathrm{CHC} .{ }^{74}$ Another anonymous Vita Athanasii preserved in an eighth-century papyrus codex (Turin) and influenced by the above mentioned passage of the $\mathrm{CHC}$, introduces a Constantine / Constantius (the two characters overlap) who exiles and recalls the orthodox bishops, among whom was Athanasius, and is ready to put Arius on trial for heresy. This episode is followed by a reworking of the famous miraculous death of Arius. What is interesting here is that, as in the $\mathrm{CHC}$, there is a reference to the father Constantine as someone of the past, who has ratified the Nicene faith with the subscription of Alexander, therefore completely unconnected with the rehabilitation of Arius. ${ }^{75}$

69 T. Orlandi, Testi copti. 1) Encomio di Atanasio. 2) Vita di Atanasio, Milano - Varese 1968. A new parallel fragment has been published by V. Ghica, A. St. Damiana “'His Toil was not in Vain'. Two Unpublished Coptic Fragments of the Encomium on Athanasius Attributed to Cyril of Alexandria (IFAO inv. 79-80)", Coptic Society, Literature and Religion, from Late Antiquity to Modern Times (cf. fn. 66) 953-968.

70 In Orlandi's manuscripts we read ...] Tantin[...which should point to Constantine (cf. fn. 69, 261. 9), while in the IFAO fragment published by Ghica (IFAO inv. 79v) the reference to Constantius, more appropriate to the chronology of the historical context, is certain.

71 Orlandi (cf. fn. 69) 26 1. 11.

72 Ghica, Damiana (cf. fn. 69) 963-964.

73 Orlandi (cf. fn. 69) 35 ll. 21-28 (text), 67 (translation).

74 Orlandi (cf. fn. 54) I, 22 1l. 12-15 (text); 58 (translation).

75 Orlandi (cf. fn. 69) 92 1.1-93 1. 1 (text) 124 (translation). 
Other texts could be mentioned in order to outline Constantine as the symbol of the ideal Christian ruler in the history of the Coptic culture, from time to time responding to different needs. For this purpose the reader can refer to the rich and detailed studies by Buzi and Luisier, but a brief mention seems necessary of the strangest text about Constantine; it includes the legend of "Eudoxia and the Holy Sepulchre" narrating the horrible death of Diocletian (an Egyptian!), ${ }^{76}$ a fabulous career of the young Constantine, and the cultic activities of a certain Eudoxia, called "his sister." This text, preserved in manuscripts of the seventh/eighth century and redacted during the seventh century, attributes the finding of the True Cross and the discovery of the Holy Sepulchre to this fictitious sister. Drake has studied this complex set of legends and views it as the product of the Coptic intellectual circles of the seventh century, who were trying to understand new power dynamics and defend their own religious traditions while living under the Arab domination. ${ }^{77}$

The change that occurred in the historiographical representation of the emperor can be measured through later texts about Jovian. Two known elements of Jovian's biography emerge in the accounts from the $C H C$ and the HP: the letter by which Athanasius is reinstalled in Alexandria - which appears reformulated by both texts when compared to the original Greek - and the accusations against him made by an Arian delegation to the emperor guided by the Arian Lucius. ${ }^{78}$ The $\mathrm{CHC}$ does not mention the letter and the Arian petitions but instead quotes the detail of the emperor's horse incitement, which is preserved only in the Greek text of Petitiones arianorum, in turn cited in the HЕрA: "and he incited his horse (аудчтєвс пєчгто) and went hunting."79 It is difficult to trace how this particular element reached the $\mathrm{CHC}$ (while it is suppressed in the $H P$ ).

The Encomium, attributed to Cyril, includes the same episode of the Arian petitions. However, in this text it is impressive how the author uses Jovian's reign as the purest example of the ideal relationship between state and church. A fictional letter written by Jovian to Athanasius declares the subordination of the secular power to the ecclesiastical one:

(...) while you take care of the churches, so that they become like heavenly things, adorned with all purity. It is not me, o holy shepherd, the one who dictates the norms († גoroc) to you, but you will be the one who gives the norms to me. Certainly it is necessary that the kings submit to the priests (мршог әүпотассе мпоүннв). Finally to all this, write to all the inhabited world to pray for my kingdom in all the churches, so that the God, Christ, may preserve me in the orthodox faith of my fathers. I inform your Holiness that Lucius of Cappadocia (whose name is not worth men-

76 On this theme see A. Papaconstantinou, "Historiography, Hagiography, and the Making of the Coptic 'Church of the Martyrs' in Early Islamic Egypt”, DOP 60 (2006) 65-86.

77 For the texts and the historical commentary, see T. Orlandi, B.A. Pearson, H.A. Drake, Eudoxia and the Holy Sepulchre. A Constantinian Legend in Coptic (Testi e documenti per lo studio dell'antichità 67), Cisalpino-Goliardica, Milano 1980.

78 Orlandi (cf. fn. 54) I, 50-52 (text), 68-69 (translation).

79 Orlandi (cf. fn. 54) I, 52 ll. 12-13 (text), 68 (translation). 
tioning) and those who are with him, who have been driven out of your city since that time, as we have witnessed, having come complained against your pity in front of us. But we have not listened to them absolutely (...)

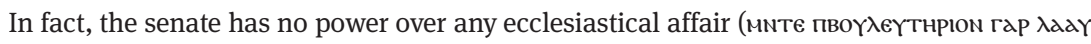

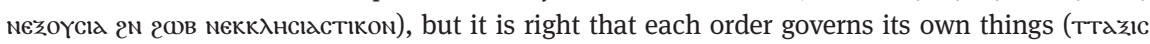

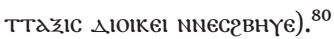

The last episode of Jovian's reign concerns a seriously ill Athanasius who, in the final days of his life, expresses the desire to see the doors of Serapis' temple closed (the $H P$ is strictly dependent on the $C H C$ for this episode):

the clergy of Alexandria is witness to the fact that before seven days had passed since his death, Jovian sent to close the door of that temple. ${ }^{81}$

It is clear here that the narration, with its chronological inversion of the death of Jovian (364) and that of Athanasius (373), presents this initiative as an anticipation of what will be the most important event in Egypt in the long agony of paganism, i.e., the destruction of the Serapeum and the statue of the divinity (392). Catherine Louis has studied and published an edition of a parchment sheet preserved in Institut Français d'Archéologie Orientale (IFAO) (inv. no. 51), ${ }^{82}$ whose text (an extract of a florilegium) deals with the final phase of the Serapeum in a legendary fashion. It contains the conclusion of an imperial letter in which the sending of a general (stratēlatēs) with troops is promised in order to close the pagan temples; at the end of the text we discover that this letter is fictionally quoted in a message of the clerics of Alexandria to the people of the city. Their signature at the end of the quotation is as follows: "the clerics of the city of Rakote (Alexandria)" (мек入нрікос мтполıс ракотє). Louis demonstrates that the lost text to which this fragment belongs was the basis of the above-mentioned passage of the $\mathrm{CHC}$ and the HP.

For the following period, the text of the $\mathrm{CHC}$ introduces Theophilus, and only later informs the readers about the succession to Jovian: Valentin(ia)nus and Valens, who are mistakenly defined as his sons and qualified as "believers," i.e., orthodox a qualification which could be deemed at least questionable in regard to Valens. ${ }^{83}$

A further sign of the growing importance assumed by Jovian as the image of the good emperor, given his advantage of being completely unrelated to later theological controversies, is the Encomium of Saint Mena published by Drescher, and attributed

80 Orlandi (cf. fn. 69) 36 1. 19-37 1. 9 (text), 69 (translation).

81 Orlandi (cf. fn. 54) II, 12 (text), 61 (translation).

82 C. Louis, "Les derniers temps du Sérapéum d'Alexandrie: un nouveau témoin copte”, Journal of Coptic Studies 17 (2015) 109-126; the last words of the text are edited at 114.

83 On the difficult question of defining Valens' religious policy, see N. Lenski: Failure of Empire. Valens and the Roman State in the Fourth Century A.D., University of California Press, Berkeley 2002. 
to John III (patriarch during the period 677-686), certainly written after the Arab conquest (which is mentioned): ${ }^{84}$

Accordingly, the chief citizens of Alexandria and those of Mariotes and all the archons of Egypt besought the holy Athanasius, the archbishop, to build a wondrous memorial-church to the glory of God and the holy Apa Mena and the joy and gladness of all the peoples who came to it. And the holy Athanasius was unable because of the trials caused by the impious Arians persecuting him. But God confounded the (vile faith) of the heretics. He raised up the just and the pious king (прро м.лікаıс аүш меүсевнс) Jovian. The Church took honour again in his days. Then the holy Athanasius undertook the carrying-out of the people's request to the glory of God and His blessed martyr. And when the God-loving king (прро ммдїмогте) Jovian heard, he wrote to the stratēlatēs of Alexandria that he should help him with money for the building of the church (in the name of) the blessed martyr. And so he gave orders with great power. He brought it to completion in all beauty, adorning it with precious marbles glistening like gold.

Again Jovian has to deal with a stratēlatēs. This time, through another fictional letter, Jovian exhorts him not to close a temple, but to find the money in order to build a church. It is to be noticed that the financial support comes from both the general and the archontes: I think that there is here an allusion not only to the rich Christian élite, but also to the engaged movement of the philoponoi. A final remark: the writer makes the same mistake as the writer of the $\mathrm{CHC}$; immediately after this passage, Valens and Valentini(an)us are defined as sons of Jovian and just emperors. Is it possible to suppose a close dependence of this late text on the $\mathrm{CHC} ?^{85}$

\subsection{The New Figures of Power: The Two Theodosii, Arcadius and Eudoxia, Marcian and Pulcheria, Justinian and Theodora}

In regards to Theophilus of Alexandria (385-412) as outlined in both the CHC and the $H P{ }^{86}$ it is worth noting that the destruction of the Serapeum (392) is left in the background and the reader is referred to a lost writing attributed to the bishop about the events surrounding the fact (it should be remembered that a mention of

84 J. Drescher, Apa Mena. A Selection of Coptic Texts Relating to St Menas, IFAO, Cairo 1946. The passage is edited at 66-67 and translated at 144-145. See also Orlandi (cf. fn. 66) 302. It should be remarked that the whole passage contains very good historical information until the time of the Arab invasion. Zeno and Anastasius are mentioned as examples of good Christian rulers in the history of Saint Mena.

85 It is noteworthy the fact that John III, the supposed author of the text, was assisted in his patriarchal activity by the scribe George, who was also his spiritual son: George in turn became secretary of the following two patriarchs and was the author of a Coptic history for the period from Cyril to the end of the seventh century, which is one of the main sources of the HP. Given his function and his historiographical attitudes, I ask myself whether this historical sketch of the sanctuary of Saint Mena is due to George rather than to his patron.

86 Evetts (cf. fn. 58) 425-430; Orlandi (cf. fn. 54) II, 12-16 (text), 61-63 (translation). 
the Serapeum occurs already in the account of Jovian's reign). ${ }^{87}$ Great emphasis is given instead to traditions concerning the most important cultic buildings, especially those in which monks and lay confraternities (the so-called philoponoi) were involved. Such memories were tied to the origins of the Christian community itself; a mention in a historical narrative was a way for these groups to enhance their own prestige in the history of Christian Alexandria. ${ }^{88}$ A famous episode, mentioned here for its relevance to the topic of the good Christian emperor, is connected with Athanasius' desire, expressed in front of monks and philoponoi, to build in his possession a martyrion for John the Baptist. ${ }^{89}$ Theophilus accomplishes this project as attested here:

Theophilus remembered the speech that his father had made about the shrine of John the Bap-
tist. He had acquired great wealth. The emperor had ordered to give him the key of the temples
and he had found great wealth. And according to the word of God and the will of his servant
Athanasius, he built the martyrion facing the garden of Athanasius and adorned it with large
ornaments, with the help of the emperors and the nobles of Egypt, who sent him gifts, gold, sil-
ver and precious stones for the construction of the shrine. And they rejoiced with him in every
region, especially the great merchants who were in India and in remote regions, who brought
him everything necessary. After it had been finished, he moved there the bones of John the Bap-
tist, and great miracles occurred during the translation of the bones of the precursor of Christ..

This passage highlights a positive custom of the empereror, his court and the provincial administration that was supposed to emanate from him: the construction of cultic buildings. Such a use supports the activities of the church while removing from society both the error of the pagan religions and the danger of heresy. Theodosius I is obviously the best representative of this ideal emperor. The so-called "the legend of the three thètas" is one of the most ideologically powerful tales elaborated in late antique Egypt related to this motif. ${ }^{91}$ It is missing from the $\mathrm{CHC}$ but occurs in the $H P,{ }^{92}$ the Annals by Eutychius, ${ }^{93}$ the Encomium of Raphael, ${ }^{94}$ the Synaxarium and

87 On the accounts about the destruction of the Serapeum, see T. Orlandi, "Uno scritto di Teofilo alessandrino sulla distruzione del Serapeum?”, La Parola del passato 121 (1968) 295-304; A. Martin, "Sarapis et les chrétiens d'Alexandrie: un réexamen”, in Alexandrie médiévale 3, ed. Chr. Décobert et J.-Y. Empereur (Études alexandrines 16), Cairo 2008, 41-57.

88 See Camplani (cf fn. 5).

89 Orlandi (cf. fn. 54) I, 46-47 (text), 66-67 (translation).

90 Orlandi (cf. fn. 54) II, 14 1l. 2-29 (text); 62-63 (translation).

91 T. Orlandi, "Teofilo e i templi pagani; Le opere di Teofilo in lingua copta", in Orlandi (cf. fn. 54) II, 95-106 and Id., "Theophilus of Alexandria in Coptic Literature”, in StP 16 (TU 129) Berlin 1985, 100 104.

92 Evetts (cf. fn. 58) 426.

93 Eutychii Patriarchae Alexandrini Annales. Pars Prior - Parts posterior, ed. L. Cheiko (CSCO 50 - 51, Scriptores arabici 6-7), Beirut - Paris 1906-1909.

94 T. Orlandi, "Raphael in Alexandria", in Philologie, herméneutique et histoire des textes entre Orient et Occident. Melanges et hommage à Sever J. Voicu, ed. by F. P. Barone, C. Macé and P. A. Ubierna, Brepols, Turnhout 2017, 225-246. See the edition in T. Orlandi, Encomium In Raphaelem Archangelum 
other texts. ${ }^{95}$ The story describes how a pious woman, while visiting Theophilus during the work for the construction of a sanctuary supported by her finances, found a stone slab engraved with three thētas. Theophilus easily recognised a real political and religious program in the stone slab by interpreting the three thètas as the initials of Theos, Theodosios, and Theophilos. Under this stone the bishops discovered a treasure that he used for the ecclesiastical constructions. Here we have an idealised representation of that link between the empire, the church of Alexandria and the Christian élite that was well represented by Theophilus' symbolic figure as reworked in later centuries. The legend acquired a considerable pace in Alexandrian circles around the late sixth century since no traces of it are detectable during Theophilus' episcopate or in the $\mathrm{CHC} .{ }^{96}$

This ideal occurs under different political circumstances, including the period under Arab domination when building a church was becoming a problem. Those accounts could be used to remind people (and the administration?) of a time in which this activity was a charge of the political power, which neither hindered the restoration of old churches nor opposed the construction of new ones but instead supported them. In the Encomium of Saint Mena, written under Arab domination, we read: ${ }^{97}$

And when some time had passed until the days of Theodosius the Great, with Arcadius and Honorius, his sons, in the days of Theophilus, the archbishop, there being great peace and prosperity in their reign, (it befell that) when the feast of the blessed martyr came round, on the fifteenth of Hathôr, many great multitudes assembled. And they suffered distress because the church could not hold the multitudes but they were standing outside in the desert. And the blessed archbishop, Apa Theophilus, was there. At the sight of the people's distress he wrote to Arcadius, the king. And the king ordered the building of a spacious memorial-church.

But the political power also had an irrational side. This was already evident at the time of the "holy" Constantine: he reacted with thymos to the new accusations against Athanasius in November 335. In the $\mathrm{CHC}$, women especially incarnate this ir-

(Relatio Theophili) Attributed to Cyril of Alexandria or Theophilus of Alexandria. Text, Latin Translation, and Diplomatic Edition of the Codices, Corpus dei Manoscritti Copti Letterari, Rome 2018 (digital edition). For the Arabic text see R.-G. Coquin, "Discours attribué au patriarche Cyrille, sur la dédicace de l'église de S. Raphaël, rapportant les propos de son oncle Théophile”, Bulletin de la Société d'Archéologie Copte 33 (1994) 25-56; “II - version arabe”, Bulletin de la Société d’Archéologie Copte 36 (1997) $9-58$.

95 For the Synaxarium see both recensions under the date 27 Bābah: Synaxaire arabe jacobite (rédaction copte), ed. R. Basset, in PO I, 3, Paris 1904, 346-347; Synaxarium alexandrinum. Pars prior, ed. I. Forget (CSCO 89-90, Scriptores arabici 18), Rome 1921, 67, see translation 72-73.

96 To this legend another one should be added concerning the youth and friendship of Emperor Theodosius and bishop Theophilus reported in the Annals by Eutychius. An analysis of the significance of this tale will be published by M. Conterno, "Whose dream comes true? Negotiation of primacy in the 'Legend of Theodosius and Theophilus", in Narrating Power and Authority in Late Antique and Medieval Hagiographies from East to West, ed. G. Dabiri, Turnhout 2021, in press.

97 Drescher (cf. fn. 84) 67-68 (text), 145-146 (translation). 
rational side by losing self-control in the exercise of power. For example, Eudoxia, the wife of Arcadius, is an evil, greedy woman, feared by all notables and clerics, whose anger cannot be controlled even by her husband Arcadius. The $\mathrm{CHC}$ pitifully explains Theophilus' attitude towards John Chrysostom with the former's intention to contain the wrath of Eudoxia against the church. ${ }^{98}$ The HP reformulated the course of events to delete from historical record Theophilus's responsibility in the exile and death of John Chrysostom. ${ }^{99}$

Theodosius II, as described in the $\mathrm{CHC}$, is also the symbol of the good emperor worthy of his office. He has a sister, Pulcheria, who helps him reign more than his own wife. His support for the patriarch Cyril is unconditional in the latter's fight against emperor Julian's pagan writings and the heresy of Nestorius. He provides the organisational and financial means to summon a Council at Ephesus in order to defend the orthodox Christology. ${ }^{100}$

However, the emperor's positive function is afflicted by potential dangers: both the lack of sons and Pulcheria's ambition are responsible for the greatest catastrophe of the Egyptian church, the Council of Chalcedon (451): ${ }^{101}$

(Theodosius the Younger) had no sons in those days and he was afflicted for that reason. His sister Pulcheria / Porcheria was virgin and lived with him in the palation. She administered the empire with his wife, but Pulcheria / Porcheria had a rod (=authority) above the one of the wife of the emperor.

The sudden death of Theodosius pushes Pulcheria into the arms of Marcian, a "Nestorian," who becomes the new emperor by marrying her. The greatest fight for orthodoxy for the Coptic Church begins from this moment. In these vicissitudes and traditions surrounding them are contained all the elements of the future antiChalcedonian polemics.

The Life of Dioscorus and the Encomium of Macarius Bishop of Tkow, written a little before or during the composition of the $\mathrm{CHC}$, are two texts that help us understand the political significance of this change of direction. The former is a pseudonymous account of the bishop's exile, preserved in Syriac and Arabic but originally written in Greek or Coptic. This text contextualises Dioscorus' vicissitude at the Council of Chalcedon into a broader narrative of Egyptian history. In the exordium the signs of the catastrophe are evoked and a famous tale is presented $(2-4):^{102}$

98 Orlandi (cf. fn. 54) II, 34-36 (text), 72-76 (translation).

99 Evetts (cf. ft. 58) 426-427, $430-431$.

100 Orlandi (cf. fn. 54) II, 36-50 (text), 76-88 (translation).

101 Orlandi (cf. fn. 54) II, 36 (text) 23-28, 76 (translation).

102 Theopistos, Vita Dioscori, ed. F. Nau, "Histoire de Dioscore, patriarche d'Alexandrie, écrite par son disciple Théopiste”, JA 10 (1903) 5-108, 241-310. See now the Arabic version: Die arabische Version der Vita Dioscori: Edition und Übersetzung (PO 56, fasc. 1), Turnhout 2016. 
The emperor Theodosius the younger had no children. He had a sister named Pulcheria who had promised before God to live in virginity (...). In the imperial palace there was a young man of good presence, named Marcian, belonging to the Nestorian sect. Satan inflamed Pulcheria's heart for this wicked man. One day to the victorious emperor Theodosius was brought a great and very beautiful apple, which he contemplated and admired. An excellent perfume exuded from it. And since there was no one to honor and esteem more than his sister, he called her and gave her this apple. This adulteress took it and sent it secretly to her impure friend, the Nestorian Marcian, because there was no man she loved more than him. Marcian in turn thought that no one else could be worthy of having this apple except the emperor. He took it and brought it to him. This one recognised the apple he had donated to his sister, but asked, as if he knew nothing: "Where does this beautiful and so remarkable apple come from?" Marcian answered him: "A general, a friend of mine, sent it to me." The emperor understood that his sister Pulcheria was burning with an adulterous love and exiled Marcian in the Thebaid of Egypt under the pretext that he was Nestorian, but, in reality, with the intention that his sister could no longer see him in Constantinople. Shortly after, the victorious Theodosius died. Satan, the cursed serpent, began his old fight against the woman. He spoke to the impure heart of Pulcheria in this way: "You remain in the inactivity and the empire of your fathers will pass to another people

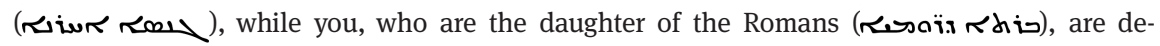
spised."

This tale served the anti-Chalcedonian propaganda with great communicative power: the turning point of the religious policy of the empire should be attributed to an act of adultery on the part of the woman who promised to maintain virginity. Its effectiveness was recognised by the other side, the Chalcedonians, who by contrast transformed it into the story first attested in Malalas. In it, Eudocia, wife of Theodosius the Younger (the ideal emperor for the anti-Chalcedonians), receives an apple from her husband and gives it to her lover Paulinus, who in turn offers it to Theodosius, allowing the latter to discover the adultery, execute him and punish Eudocia with exile in Jerusalem. ${ }^{103}$ The fact that Theodosius did not have children along with the vow of chastity by his sister Pulcheria are elements of an unstable equilibrium which, as soon as it was disturbed, gave rise to a dynamic that was destined to have a fatal outcome. Satan intervened, just as he did in the days of Eve, to push Pulcheria to sin, suggesting that she should fear that power might not remain in the hands of the Romans but be destined to move to other families or populations. Burgess has dedicated a long article to the history of Marcian's representation ${ }^{104}$ and Scott has masterfully delved into some of his insights. ${ }^{105}$ The two have demonstrated well how the story was so successful that the front of Chalcedon was obliged to rework and rewrite it, implicitly recognizing its communicative power.

103 Johannes Malalas, Chronographia 14, ed. L. Dindorf, Bonn 1831, 356-357.

104 R.W. Burgess, "The Accession of Marcian in the Light of Chalcedonian Apologetic and Monophysite Polemic”, BZ 86 (1993-1994) 747-768.

105 R. Scott, "From Propaganda to History to Literature: The Byzantine Stories of Theodosius' Apple and Marcian's Eagles", in Id., Byzantine Chronicles and the Sixth Century (Variorum), Farnham, Surrey - Burlington 2012, n. XVI. 
In the Encomium of Macarius of Tkow, 3-4, ${ }^{106}$ Pulcheria's betrayal is described in apocalyptic terms within a vision narrated by the hero of the story:

\begin{abstract}
It was as if the holy bishop and martyr, Father Psote of Psoi, stood there, and all of the bishops stood there. And you and I also, we stood there. I saw in the vision shining crowns upon all our heads ( $R v$ 4:4). I saw Athanasius, the archbishop, saying to Father Psote, the bishop: 'O holy martyr, the fathers at the throne ( $\operatorname{Rv} 4: 4.9)$ are those who say to you: Appraise the bishops. Will they fight well or not?' And I saw him who opened a gate of darkness. He called inside saying: 'Ancient serpent (Rv 12:9; 20:2), come out!' And at once I saw a large dragon with a papyrus tome (томос мхартнс) transfixed in his mouth. And I also heard a voice in the darkness behind the dragon, saying: 'Pulcheria, Pulcheria, take this to yourself and give it to Marcian, for the sixth day is finished. He who reads, let him understand.' At once I saw the woman whose name we pronounced, and she, having straightened out her purple (robe), took it to herself. I also saw her passing it to another who was beside her. And I saw little snakes also coming out of the large dragon's mouth. They went over beside the man who held the papyrus. They kept encouraging him.
\end{abstract}

In this account, Pulcheria is the great harlot, Marcian is connected to the dragon and the beast, and the orthodox bishops are the apocalyptic elders, destined to salvation. The references to Revelation could be easily multiplied beyond the ones I have pointed out, but the general meaning of the passage is unequivocal: the political power must remain orthodox, otherwise it is destined to be transformed into a Satanic tyranny, an anticipation of the Antichrist.

When we turn our attention to the account of Peter Mongus' life in the HP (n. 27), the Coptic source chosen by the compiler is no longer the $\mathrm{CHC}$, but probably the history written by George under the Arab domination, which included the period from Cyril to his own time (eighth century, under the patriarch John III). The attitude towards the empire of the post-Chalcedonian era changed dramatically, as can be gleaned from the following passage, where the Roman Empire as such is no longer considered the political structure of reference:

So when Timothy went to the Lord, Peter the priest was ordained by command of God in the church of Alexandria, and was made patriarch. But the empire of the Romans remained established upon the ever-renewed memory of the impure council of Chalcedon; for it was not built upon the foundation of the firm Rock, which belongs to God the Word who is Jesus Christ. ${ }^{107}$

It is from this same source, and according to the same ideological perspective, that HP has drawn some of its materials about Justinian and Theodora, the last figures which we will take into consideration here. The imperial couple is the most important for the Coptic identity for the simple reason that Justinian's persecution pro-

106 A Panegyric on Macarius, Bishop of Tkôw, Attributed to Dioscorus of Alexandria, ed. and trans. by D.W. Johnson (CSCO 415-416, Scriptores coptici 41-42), Louvain 1980. The passage is at 8-11 (text), 6-9 (translation). See Orlandi's Italian translation (cf. fn. 66) 164-165.

107 Evetts (cf. fn. 58) 445-446. 
voked the birth of an alternative clerical hierarchy in Egypt in the second half of the sixth century, that is, the Coptic Church, with its own religious ideology and perspective on its past. ${ }^{108}$ The historical account in this section of HP has three main characters (Life 33): Justinian, who uses every means to obtain his purpose of obliging the bishops to sign the heretic definition of Chalcedon and the Tome of Leo; bishop Theodosius of Alexandria, representative of the martyrial tradition of Mark, Peter, Athanasius, Dioscorus, ready to resist the imperial flattery in the name of the traditional faith; and Theodora, who, as the opposite of Eudoxia, is particularly sensitive to bishop Theodosius' holiness. Justinian is explicitly compared to Satan, the tempter mentioned in Matthew and Luke. However bishop Theodosius refuses the temptation of religious, economic, political power, so that no other option is left to the emperor than to persecute the orthodox believers in Egypt, close the churches, exile Theodosius in Constantinople. Other texts offer similar scenes, characterised by a similar balance of attitudes. For example, in the Coptic Panegyric on Manasseh, ${ }^{109}$ the anti-Chalcedonian monk Abraham of Farshut is described as prisoner in Constantinople while resisting the emperor (преро) ${ }^{110}$ and being supported by the empress (тр्p()), who at the end has to give up because of the violent attitude of Justinian. In a Coptic chronicle, a possible source used in HP, the conversations of bishop Theodosius and emperor Justinian in the imperial court of Constantinople are reported with the aim of showing both Justinian's sophisticated means of persuasion, based on his and his collaborators' theological culture, and the resistance of Theodosius, who knows how to face the imperial pressure with the weapons of tradition. ${ }^{111}$

Stephen of Herakleopolis Magna uses Revelation to connect the era of Marcian with that of Justinian in the Panegyric of Apollo, in which Justinian is the representative of a satanic line of action in history comparable to a "a hidden fire in chaff which continues to produce smoke" $(8-9):{ }^{112}$

$108 \mathrm{Ph}$. Booth, "A Circle of Egyptian Bishops at the End of Roman Rule (c. 600). Texts and Contexts", Mus 131 (2018) 21-72; Id., "Towards the Coptic Church: The Making of the Severan Episcopate”, Millennium 114 (2018) 151-189.

109 Ed. J.E. Goehring, Politics, Monasticism, and Miracles in Sixth Century Upper Egypt: A Critical Edition and Translation of the Coptic Texts on Abraham of Farshut (Studien und Texte zu Antike und Christentum 69), Tübingen 2012, 116.

110 Abraham prefers martyrdom, as the texts says, rather than to "be cast into punishment like Nestorius and Arius and Juvenal and Marcian and the rest who have repudiated the faith of the Son of God" (ibid., 116-117). The Coptic text has маркіanoc; Goehrings translates "Marcion", but here the reference is clearly not to the second century heretic but to emperor Marcianus, symbol of the Nestorian / Chalcedonian heresy, who in the list is close to Bishop Juvenal of Jerusalem, the traitor who abandoned the tradition of Cyril of Alexandria and adhered to the Chalcedonian heresy.

111 R.-G. Coquin, "Fragments d'une chronique, relatifs à un patriarche d'Alexandrie, sans doute Théodose (535-566 A.D.)”, Bulletin de la Société d'Archéologie Copte 30 (1991) 1-24.

112 Ed. in A Panegyric on Apollo, Archimandrite of the Monastery of Isaac, by Stephen bishop of Heracleopolis Magna, ed. trad. by K.H. Kuhn (CSCO 394-395, Scriptores coptici 39-40), Louvain 1978, 14-15 (text), 10-11 (version). 
Suddenly the sky became thick with clouds. Great hail rained from on high upon men (Rv 16:21) not according to virtues' desert. Then the lion that had been hidden came forth from his lair to seize someone. I saw, said John in his Apocalypse, a star that had fallen from heaven. The pit of the abyss was opened. Smoke of a great fire went up. The sun and the air became dark through the smoke of the pit (Rv 9:1-2), the pit of the impiety which the rulers had gathered up who had come together to Chalcedon. This very pit of the abyss was opened again in the days of the Emperor Justinian. Again that soul-destroying madness, again the torrents of lawlessness flowed in their ravines to shake the house of the faithful. For after Marcian, the originator of the innovation of the faith, had finished, and after Basiliscus and Zeno and still others after these, the bad weed grew again in the kingdom of Justinian like a hidden fire in chaff which continues to produce smoke. Now the wretched bishops who had come together at Chalcedon became food for perdition and death and error, but their sins continue to be active. And their wickedness was unending and their punishment also is unceasing. For the fire of apostasy which those wretched bishops kindled everywhere drew to itself the laments and tears of the holy prophets unto the end. For let the pine tree weep, said the prophet Zechariah, because the cedar has fallen (Zec 11:2). This means: Let the people weep, for their bishops have fallen in a fall deliberately chosen, that is of their deliberate choice. Jeremiah also laments over them, saying: Many shepherds have destroyed my vineyard (Jer 12:10). I shall yet adduce another third prophetic lament, for their impiety is against the Trinity. Woe to the peoples, said Nahum, for their shepherds have slumbered in spirit. The king of the Assyrians who is hidden has laid to rest a ruler, for the rulers of the church are the bishops, as the holy apostles said. There is no healing, he said, for their ruin (Na 3:18-19).

\section{Conclusion}

In this contribution we have discussed a limited number of texts, which may be categorised as historiographical and hagiographical - that is, different ways of writing history - composed within environments close to the religious power, particularly the patriarchate. Our purpose was to draw out from these narratives different ideas of the good Christian emperor, to compare them in order to identify elements of transformation and continuity over time, and to understand what changing needs they were meant to address. Through the analysis of some characters and images reported in these works an outline has been offered of the various and evolving conceptions regarding both the role of the Alexandrian see within the political system of the eastern Roman Empire and the function of the emperor responsible for the search of the true public religion of the empire.

The role of Athanasius, as both a historical character (exiled by the first Christian emperor, Constantine) and a writer able to select documents and create stories about himself and other historical actors, has been emphasised because his influence extends over the centuries and in different contexts thanks to the images created by him and his statements about the relationship between church and political power. Athanasius' model of writing history and personal defense exerted its influence on the HEpA and Timothy Aelurus' historical work. The latter too appears affected by Athanasius' style of polemics, but also as a creator of new images and ideas, in turn reworked in later literature. One such motif is the contrast between the happy 
times of Cyril of Alexandria and Emperor Theodosius the Younger when church and state were cooperating, and the dark times of the Emperor Marcian and Leo's Tome, connected to the arrival of the Antichrist, when passions for money, career, and sex corrupted the exercise of the public power.

At the same time, hagiographic texts such as the Life of Dioscorus and the Panegyric of Macarius placed emphasis on the stories concerning the representatives of the political power, such as the "adulterous" relationship between Marcian and Pulcheria, or the servile attitude on the part of some bishops towards the emperors. These texts connect the first phase of Alexandrian historiography to the next one.

A second phase in the conceptualisation of the past begins with the redaction of the Coptic History of the Church (dated to the sixth century), which gives a good indication of the evolving identity of the Egyptian church both in its internal structure and in its relationship with the empire, that, in spite of everything, remained its fundamental political framework, not questioned by any form of nationalism. The text also pays attention to the irrational side of power, which is expressed especially through the political and ecclesiastical action of women like Eudoxia and Pulcheria, and contrasted by Theodora who, according to some historical accounts, was sensitive to the holiness of the "orthodox" bishops. This is the period in which a new church was born, separate from the Chalcedonian one often supported by the empire. Of course the conception of political power is deeply affected by the motif of Christological orthodoxy: the emperor must be "orthodox" if he wants to be a good emperor. But the choice of the Roman Empire was to gradually embrace the Chalcedonian heresy; Marcian and Justinian were the main promoters of this line of religious policy.

The author (authors) of Coptic History of the Church collected Coptic homilies and traditions about cultic establishments, while the references to real documents are rare. In this late production, references to fourth century emperors such as Constantine, Constantius, and Jovian allowed Egyptian historians to express additional traits of the ideal good emperor. He is not only the one who destroys pagan cults and supports the church against heresy, punishing deviations, but also the one who, through his political and social mediations, favours the expansion of ecclesiastical structures on the territory and their urban visibility by supporting the cult in all its forms, and strengthening social cohesion among the different civil and ecclesiastical actors. It should be questioned if the image of the emperor as "builder" answers only to late antique needs or is connected also to the new situation of Christians under the Arab rule, when the restoration of old churches, but above all the construction of new ones, could become a difficult question, to which some homilies tried to find different solutions. 
